Angelo Ravelli, MD

\title{
Handbook of Juvenile Idiopathic Arthritis
}


Angelo Ravelli, MD

University of Genoa

Giannina Gaslini Institute

Genoa, Italy

\section{Handbook of Juvenile}

Idiopathic Arthritis 


\author{
Angelo Ravelli, MD \\ University of Genoa \\ Giannina Gaslini Institute \\ Genoa, Italy
}

ISBN 978-3-319-08101-4 ISBN 978-3-319-08102-1 (eBook)

DOI 10.1007/978-3-319-08102-1

Springer Cham Heidelberg New York Dordrecht London

(c) Springer International Publishing Switzerland 2016

This work is subject to copyright. All rights are reserved by the Publisher, whether the whole or part of the material is concerned, specifically the rights of translation, reprinting, reuse of illustrations, recitation, broadcasting, reproduction on microfilms or in any other physical way, and transmission or information storage and retrieval, electronic adaptation, computer software, or by similar or dissimilar methodology now known or hereafter developed. Exempted from this legal reservation are brief excerpts in connection with reviews or scholarly analysis or material supplied specifically for the purpose of being entered and executed on a computer system, for exclusive use by the purchaser of the work. Duplication of this publication or parts thereof is permitted only under the provisions of the Copyright Law of the Publisher's location, in its current version, and permission for use must always be obtained from Springer. Permissions for use may be obtained through RightsLink at the Copyright Clearance Center. Violations are liable to prosecution under the respective Copyright Law.

The use of general descriptive names, registered names, trademarks, service marks, etc. in this publication does not imply, even in the absence of a specific statement, that such names are exempt from the relevant protective laws and regulations and therefore free for general use.

While the advice and information in this book are believed to be true and accurate at the date of publication, neither the authors nor the editors nor the publisher can accept any legal responsibility for any errors or omissions that may be made. The publisher makes no warranty, express or implied, with respect to the material contained herein.

Printed on acid-free paper

Adis is a brand of Springer

Springer is part of Springer Science+Business Media (www.springer.com)

Project editor: Laura Hajba 
To Laura, Giovanni, and Serena 


\section{Contents}

Author biography xi

Abbreviations xiii

1 Introduction 1

Disease overview 1

$\begin{array}{ll}\text { Epidemiology } & 1\end{array}$

Etiology and pathogenesis 2

Environmental factors 2

Genetic susceptibility 2

Role of humoral and cell-mediated immunity $\quad 5$

$\begin{array}{ll}\text { Pathogenesis of systemic arthritis } & 7\end{array}$

$\begin{array}{ll}\text { Pathophysiology of macrophage activation syndrome } & 9\end{array}$

$\begin{array}{ll}\text { References } & 10\end{array}$

2 Disease classification $\quad 17$

$\begin{array}{ll}\text { Classification criteria } & 17\end{array}$

$\begin{array}{ll}\text { Challenges in classification } & 17\end{array}$

$\begin{array}{ll}\text { References } & 23\end{array}$

3 Clinical manifestations $\quad 25$

Systemic arthritis $\quad 25$

$\begin{array}{ll}\text { Rheumatoid factor-negative polyarthritis } & 27\end{array}$

$\begin{array}{ll}\text { Rheumatoid factor-positive polyarthritis } & 28\end{array}$

$\begin{array}{ll}\text { Oligoarthritis } & 29\end{array}$

$\begin{array}{ll}\text { Enthesitis-related arthritis } & 31\end{array}$

$\begin{array}{ll}\text { Psoriatic arthritis } & 32\end{array}$

$\begin{array}{ll}\text { Undifferentiated arthritis } & 32\end{array}$

$\begin{array}{ll}\text { References } & 33\end{array}$

4 Diagnosis $\quad 35$

Clinical assessment $\quad 35$

$\begin{array}{ll}\text { Imaging } & 38\end{array}$ 
$\begin{array}{ll}\text { Biomarkers } & 48\end{array}$

Differential diagnosis $\quad 51$

References $\quad 53$

5 Consequences and complications $\quad 59$

Disease course of different subtypes $\quad 59$

$\begin{array}{ll}\text { Skeletal and growth abnormalities } & 60\end{array}$

Ophthalmologic complications $\quad 63$

Macrophage activation syndrome $\quad 65$

$\begin{array}{ll}\text { References } & 70\end{array}$

6 General treatment aspects $\quad 73$

$\begin{array}{ll}\text { Goals of treatment } & 73\end{array}$

$\begin{array}{ll}\text { Measuring treatment response } & 73\end{array}$

$\begin{array}{ll}\text { Treatment recommendations } & 78\end{array}$

A multidisciplinary approach to treatment 82

Special considerations in the pediatric patient $\quad 82$

References $\quad 82$

\section{Management of patients with juvenile} $\begin{array}{ll}\text { idiopathic arthritis } & 87\end{array}$

$\begin{array}{ll}\text { Psychosocial factors } & 87\end{array}$

Physical therapy $\quad 88$

Other non-pharmacologic interventions $\quad 88$

Non-steroidal anti-inflammatory drugs $\quad 88$

$\begin{array}{lr}\text { Intra-articular corticosteroids } & 89\end{array}$

$\begin{array}{ll}\text { Systemic corticosteroids } & 93\end{array}$

Conventional disease-modifying anti-rheumatic drugs 94

Biologic disease-modifying anti-rheumatic drugs 95

$\begin{array}{ll}\text { Safety of biologics } & 102\end{array}$

$\begin{array}{ll}\text { Other pharmacologic interventions } & 104\end{array}$

Management of iridocyclitis 105

Management of macrophage activation syndrome 106

$\begin{array}{ll}\text { References } & 108\end{array}$ 
8 Specific issues $\quad \mathbf{1 1 5}$

$\begin{array}{ll}\text { Health-related quality of life } & 115\end{array}$

$\begin{array}{ll}\text { Vaccination } & 116\end{array}$

$\begin{array}{ll}\text { Treatment discontinuation after disease remission } & 117\end{array}$

$\begin{array}{ll}\text { Transition to adult care } & 118\end{array}$

$\begin{array}{ll}\text { References } & 119\end{array}$

9 Outcome, prognosis and future outlook 121

$\begin{array}{ll}\text { Long-term outcome and its prediction } & 121\end{array}$

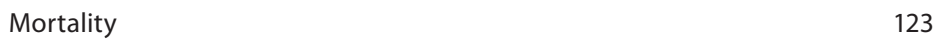

$\begin{array}{ll}\text { Future outlook } & 123\end{array}$

$\begin{array}{ll}\text { References } & 124\end{array}$ 


\section{Author biography}

Angelo Ravelli, MD, is Associate Professor of Pediatrics at the University of Genoa and Giannina Gaslini Institute, Genoa, Italy. He obtained his medical degree and specialty in Pediatrics, Allergy, and Clinical Immunology at the University of Pavia, Italy. He is also Chief of the Rheumatology Center at the Istituto Giannina Gaslini, Genoa, Italy. His field of clinical and research activity focuses on pediatric rheumatology. He has received numerous grants and awards, including the Gerolamo Gaslini Prize for Excellence in Research in 2004 and a grant from the American College of Rheumatology (ACR) and European League Against Rheumatism (EULAR) to develop the classification criteria for macrophage activation syndrome in systemic juvenile idiopathic arthritis. Professor Ravelli is Associate Editor of Pediatric Rheumatology Online Journal, Assistant Editor of Clinical and Experimental Rheumatology, and serves or has served on the Editorial Board of The Journal of Rheumatology, Arthritis Care \& Research, and RMD Open. He is also a member of the Executive Committee of the Foundation for Research in Rheumatology (FOREUM). Professor Ravelli was the chairman of the International Consensus Conference, which led to the development of the classification criteria for macrophage activation syndrome in systemic juvenile idiopathic arthritis (Genoa, Italy, 21-22 March 2014). Professor Ravelli has been invited to speak at more than 200 national and international meetings, and is author or co-author of more than 250 full-length articles in international scientific journals and of more than 15 book chapters. His current Google Scholar h-index is 59. 


\section{Abbreviations}

ACR American College of Rheumatology

AE Adverse events

ANA Antinuclear antibodies

AS Ankylosing spondylitis

ASCT Autologous stem cell transplantation

ATG Anti-thymocyte globulin

BC Baker cyst

BSPAR British Society for Paediatric and Adolescent

Rheumatology

CACP Camptodactily-arthropathy-coxa vara-pericarditis syndrome

CARRA Childhood Arthritis and Rheumatology Research

Alliance

CCL5 Chemokine ligand 5

CCP Cyclic citrullinated peptide

CHAQ Childhood Health Assessment Questionnaire

cJADAS Clinical JADAS

COX Cyclo-oxygenase

CRP C-reactive protein

CSA Cyclosporin A

DCE-MRI Dynamic contrast enhanced MRI

DMARD Disease-modifying anti-rheumatic drugs

ERA Enthesitis-related arthritis

ESR Erythrocyte sedimentation rate

ETN Etanercept

EULAR European League Against Rheumatism

FC Femoral condyle

FHLH Familial HLH

GM Gastrocnemius muscle

GWA Genome-wide association

HLA Human leukocyte antigen 
HLH Hemophagocytic lymphohistiocytosis

HRQoL Health-related quality of life

hsCRP High sensitivity CRP

IACI Intra-articular corticosteroid injection

IGF-1 Insulin-like growth factor 1

IL Interleukin

IL-1RA IL-1-receptor antagonist

ILAR International League of Associations for Rheumatology

IRF5 Interferon regulatory factor 5

JADAS Juvenile Arthritis Disease Activity Score

JAMAR Juvenile Arthritis Multidimensional Assessment Report

JAPAI Juvenile Arthritis Parent Assessment Index

JCA Juvenile chronic arthritis

JIA Juvenile idiopathic arthritis

JRA Juvenile rheumatoid arthritis

JSpADA Juvenile Spondyloarthritis Disease Activity Index

MAS Macrophage activation syndrome

MMP-3 Matrix metalloproteinase-3

MP Methylprednisolone acetate

MRI Magnetic resonance imaging

MRP Myeloid-related protein

MTX Methotrexate

NK Natural killer

NSAID Non-steroidal anti-inflammatory drug

PCROs Parent- and child-reported outcomes

PDN Prednisone

PRCSG Pediatric Rheumatology Collaborative Study Group

PRES Paediatric Rheumatology European Society

PRINTO Pediatric Rheumatology International Trials

Organization

RA Rheumatoid arthritis

RF Rheumatoid factor

SAEs Serious adverse events 
sCD163 Soluble CD163

SEA Seronegative enthesitis and arthritis syndrome

sIL-2R $\alpha \quad$ Soluble interleukin-2 receptor $\alpha$

SNP Single nucleotide polymorphism

SUN Standardization of Uveitis Nomenclature

TH Triamcinolone hexacetonide

TLR Toll-like receptor

TMJ Temporomandibular joint

TNF Tumor necrosis factor

VAS Visual analog scale 